\title{
METAKOGNITIVNÍ PROJEVY U ŽÁKŮ S NADÁNÍM $\checkmark$ PRŮBĚHU ŘEŠENÍ NESTANDARDNÍCH ÚLOH
}

\author{
Dagmar Málková1, Darina Jirotková² \\ ${ }^{1}$ Univerzita Karlova, katedra preprimární a primární pedagogiky \\ ${ }^{2}$ Univerzita Karlova, katedra matematiky a didaktiky matematiky \\ OJPPE 3 (1) - Recenzované články/Reviewed Papers \\ Publikováno/Published 8. 10. 2019 \\ DOI: 10.21062/ujep/328.2019/a/2533-7106/OJPPE/2019/3/16
}

\begin{abstract}
Abstrakt
Všechny děti maji právo být vzdělávány, a to v prostředí, které je rozvijí optimálně do jejich osobního maxima. Maji také právo pracovat ve společné sociálni skupině. Je zřejmé, že naplňováním myšlenek inkluze vznikaji třídy výkonově značně heterogenní a mentální rozpětí žákủ v jedné třídě je značné. To klade nesmírné nároky na učitele, na jeho schopnost diferencovat výuku a pohotově individualizovat zadání úloh. Podpora žákủ s SPU se intenzivně řeší, ale systematická podpora žáků s nadáním zatím rozšiřrena není. $V$ článku seznamujeme s prvními výsledky výzkumu, ve kterém se věnujeme žákům nadaným a snažíme se popsat jejich metakognitivní procesy. Cílem je lépe těmto žákům porozumět a poznatky využít pro jejich efektivnějši výuku.
\end{abstract}

Klíčová slova: Metakognice, vyučování matematice, žák s nadáním, nestandardní aplikační úlohy.

\section{ÚVOD}

Školní vzdělávací systém prochází v současné době velkou proměnou. Velký tlak je veden na kvalitu výuky, tím pádem na kompetence učitele. $O$ efektivitě konstruktivistického př́stupu $\mathrm{k}$ vyučování matematice se hovoří již dlouho. Jedním z výzkumům zabývající se touto problematikou v předmětu český jazyk je Konstruktivismus jako cesta ke zlepšování výsledků vzdělávání v českém jazyce? (Štěpáník, Chvál, 2016). V závěrech práce Štěpáníka, Chvály $(2016$, s. 51) „... se jeví tradičně pojatá výuka jako méně funkčnív té části, kdy maji žáci prevést nabyté znalosti do komunikačni praxe při tvoření vlastnich projevü. Žáci obstojí v tradičních cvičeních, tj. většinou izolovaných transformacích, obměnách, kategorizaci, doplňováni apod., k transferu při praktické stylizaci jejich vlastních komunikátů však dochází omezeně. Naopak u přistupu využívajicíiho ve výuce konstruktivistické prvky se zdá, že převoditelnost poznatků je snazší, prímějši, čímž se potvrzuje, že vhodnou strategii ke zvýšení transferu je právě aktivní problémově pojatá práce sjazykovým materiálem." Nedobré výsledky českých studentů se objevují i v mezinárodních srovnávacích testech, TIMSS či PISA, a vyvolávají pochybnosti o tom, zda školy zvládají určovat kvalitu výuky a provádět evaluaci své práce ve školních kurikulech (Janík a kol., 2007). Z obou těchto výzkumů vyplývá, že je potřeba pozměnit výuku. Dnes již prokazatelně efektivním vyučovacím stylem je tzv. konstruktivistický. Je protipólem k „tradičnímu“ (transmisivnímu, istruktivnímu) vyučování. Desatero konstruktivismu v matematice formuloval Kuřina, Hejný $(2001,2009)$. Obšírně se myšlenkami konstruktivismu, podnětné výuky, tvořivého učení věnuje Vondrová (2007, In Hošpesová, Vondrová, Tichá, 2007) v kapitole knihy Cesty zdokonalování kultury vyučování matematice. Pro nás je obzvláště zajímavý pohled na konstruktivisticky pojatou výuku badatele v oblasti výuky českého jazyka, který je zcela v souladu s pohledy didaktiků matematiky. Podle Štěpáníka (2014) je vymezena následujícími kritérii: „(1) konstruktivismus znamená aktivní konstrukci znalostí; (2) konstruktivistický učitel počítá s dosavadním poznáním žáků, aktivně ho využívá a dále s ním pracuje; (3) konstruktivistický učitel hledá a oceňuje perspektivu žákü; (4) konstruktivistický učitel pracuje s velkými celky, nikoliv s detaily; (5) konstruktivistický učitel klade důraz na relevanci učiva pro žáky a jejich každodenní zkušenosti, zar̆azuje učivo do kontextu světa; (6) konstruktivistický učitel použivá komplexní a longitudinální hodnoceni." Výuka žáků se na základě známých výzkumů mění. V rámci požadovaných změn výuky, které jsou v souladu s posledním vymezením matematické gramotnosti Českou 
školní inspekcí ${ }^{1}$, je kladen tlak také na učitele, aby používali různé organizační formy a metody práce. I v tomto aspektu je potřeba zohledňovat jak práci se žáky s SPU, tak žáky s nadáním.

Intelektové nadání je synonymem ke slovu nadání, talent. H. Gardner vymezuje sedm typů inteligence, které zařazují intelektově nadaného člověka do určité skupiny (verbální, logicko-matematická, prostorová, muzikálně pohybová, přírodní, personální (Laznibatová, 2012). Intelektovým schopnostem žáků s nadáním je potřeba věnovat péči, aby se rozvíjeli jak v oblasti kognitivní a metakognitivní, tak také v oblasti sociální. Jejich postupy a způsoby řešení se často zdají být ostatním žákům, ale i učitelům složité, těžké, a proto je pro mnohé učitele náročné umožňovat těmto žákům další rozvoj. Proto začaly vznikat například třídy s vybranými žáky na matematiku v rámci školy, ale také se na nadané žáky profilují celé školy, např. Základní škola náměstí Curieových, kde působí jedna z autorek jako učitelka, či Mensa gymnázium.

Pokud učitel dokáže s těmito nadanými žáky pracovat $\mathrm{v}$ „normálni““ třídě, může to být velkým přínosem jak pro celou třídu, tak i pro daného žáka. Je velmi důležité, aby se dbalo na celkový rozvoj jejich osobnosti. Většinou vyřeší jednodušší úlohy hned. Při verbalizaci způsobu řešení jsou si nejistí, protože obvykle nenacházejí rovnocenného komunikačního partnera. Podle našich zkušeností se iv popisování situací ztrácí. Pečlivá verbalizace postupu a řešení je také důležitým prvkem celkového rozvoje osobnosti a v souvislosti s autoregulací učiva se jedná o velmi důležitý pojem. S autoregulací učiva úzce souvisí pojem metakognice neboli to, jak žák přemýšlí o svém plánování, postupu a hodnocení práce. V následujícím odstavci vymezíme tento pojem zejména pro potřeby naší práce.

\section{METAKOGNICE}

Jednoduše Ize říci, že metakognice je myšlení o myšlení. Autor tohoto pojmu, John Flavell jej vymezuje takto: „metakognice je znalost zahrnující kognitivní procesy a produkty či cokoliv, co se jich týká." (Říčan, 2016, s. 15). Jedná se tedy o kognitivní procesy a jejich výsledky, které ovlivňují způsob naší práce a řešení problémů. Z tohoto vymezení vychází také Průcha, Walterová, Mareš (2013, s. 153), kteří metakognici definují ve třech rovinách:

- Schopnost člověka, který přemýšlí o tom, jak uvažuje a jakým způsobem poznává svět. Cílem tohoto pojetí je zlepšení poznávacích schopností jedince.

- Schopnost člověka vědomě kontrolovat a řídit svoje poznávací schopnosti, díky kterým může postupovat úspěšně v řešení problému a dojít k cíli.

- Schopnost člověka hodnotit zadané úkoly a své možnosti, které jsou potřeba k vyřešení problému. Jedinec také kontroluje a usměrňuje svoje poznávací procesy a hodnotí, jak jeho cesta k cíli odpovídá úkolu.

Vzhledem ke vzorku žáků, se kterými máme možnost pracovat, nás zajímá kvalitativní zkoumání metakognice. Kvalitativní standard vychází z predpokladu, že metakognici lze zkoumat na základě vztahu konkrétního zadaného problému a dané strategie. To znamená, že budeme zkoumat, jakým způsobem nejdřive jedinec rozpoznal a uchopil zadaný úkol a jakou strategii k jeho řešení zvolil. To znamená, jak je vzhledem k danému úkolu daná strategie efektivní. (Říčan, 2016)

\section{OBSAH UČIVA V MATEMATICE}

Obsah učiva v matematice na prvním stupni základní školy je dán rámcově vzdělávacím programem a je konkretizován ve vzdělávací oblasti Matematika a její aplikace. „Vzdělávací oblast Matematika a její aplikace je v základním vzdělávání založena především na aktivních činnostech, které jsou typické pro práci s matematickými objekty a pro užití matematiky v reálných situacích. Poskytuje vědomosti a dovednosti potrebné vpraktickém životě, a umožňuje tak získávat matematickou gramotnost. Pro tuto svoji nezastupitelnou roli prolíná celým základním vzděláváním a vytváří předpoklady pro dalši úspěšné studium.

Vzdělávání klade důraz na důkladné porozumění základním myšlenkovým postupům a pojmům matematiky a jejich vzájemným vztahům. Žáci si postupně osvojuji některé pojmy, algoritmy, terminologii, symboliku a způsoby jejich užití." (RVP ZV, 2016, s. 30) Mezi cíle matematiky nepatři jen osvojit si učivo, ale je to

\footnotetext{
1 http://www.niqes.cz/Niqes/media/Testovani/KE\%20STA\%c5\%bdEN\%c3\%8d/V\%c3\%bdstupy\%20KA1/MG/Metodika-prohodnoceni-rozvoje-MG.pdf
} 
především schopnost přemýšlet, argumentovat a propojovat si fakta. Jedná se o kompetence potřebné pro běžný život.

Cíle vyučování matematice zcela jasně nastavují i cíle rozvoje metakognitivních postupů. Žáci řeší problémy, jejichž postup řešení je pro ně dosud neprobraný a je tedy výzvou. Tím se otevírá možnost několika různých cest k nalezení řešení, možnost porovnání několika způsobů řešení a hledání efektivního způsobu vzhledem k úrovni tř́́dy, či jedince.

\section{Nestandardní úlohy}

Nestandardní úlohy jsou zařazeny dle Rámcově vzdělávacího programu do Nestandardních aplikačních úloh. Nestandartní aplikační úlohy nemusí vycházet ze školních znalostí žákủ, ale pro jejich vyřešení je nutné logické uvažování. Tyto úlohy jsou často mezipředmětově zaměřené a mají praktické využití v reálném životě. (RVP ZV, 2016) Jejich zařazení do běžné výuky je vyžadováno. Je pak samozřejmě otázkou, jak s nimi učitel pracuje. Jejich zařazení do práce snadanými žáky je důležité. Podle naší zkušenosti i podle mnoha výzkumů u těchto úloh často selhávají žáci, kteři matematiku uchopují pamětí, učí se vzorové postupy řešení, ale podstatě nerozumí. Pro žáky tvořivé jsou takovéto úlohy přiležitostí rozvíjet svůj potenciál tím, že hledají svůj nový způsob řešení. Cílem vyučování matematice je samož̌ejmě rozvoj logického myšlení, a tedy rozvoj schopnosti argumentace vlastního postupu řešení, což tematický okruh Nestandardní aplikační úlohy vyžaduje. Kromě samotného uvažování a myšlení je možné užívat i výpočetní techniku, např. kalkulátory, nebo vhodný počítačový software (RVP ZV, 2016), který jim ušetří pracovní pamět na kognitivní a metakognitivní procesy.

\section{ŽÁK S NADÁNÍM}

Ve svém vyučování i ve svém výzkumu se věnujeme žákům s matematickým nadáním, proto se pokusíme takového žáka popsat. Žáci s nadáním se často opomíjejí, nebot' to jsou z pohledu učitele často ti žáci, kteř́ jsou šikovní a mají vše rychle hotovo. Často je pak učitelé zaměstnávají další prací na stejné kognitivní úrovni. V současné době, kdy školy více spolupracují s pedagogicko psychologickými poradnami, bývá žákovo diagnostikované nadání často kombinované s přidruženým znevýhodněním, např́klad porucha pozornosti, ADHD, či dyslexie. Jedná se pak o dvojí výjimečnost. V tomto př́padě již neplatí, že tito žáci vždy vše mají rychle hotovo a jsou šikovní, ale pak i tito žáci potřebují svůj dostatek času a prostoru k vyřešení daného problému.

Hartl, Hartlová (2000, s. 338) vymezují nadání jako „soubor vloh jako prèedpoklad k úspěšnému rozvijení schopností; nejčastěji použivání ve spojení sjedinci podávajicími nadprůměrné výkony při činnosti tělesné i duševni. " Novější vymezení tohoto pojmu nalezneme v Pedagogickém slovníku (Průcha, Walterová, Mareš, 2009, s. 164): „V pedagogickém pojetí převládá tradiční představa o nadání jako o výjimečné složce osobnosti některých jedinců, zejména pro umělecké obory, pro sport, jazyky a matematiku." Obě vymezení se shodují $v$ tom, že se jedná o něco výjimečného, co se projevuje v oblasti duševní i tělesné. Nadání se ale také nemusí projevit, když žák $\mathrm{k}$ tomu nedostane príležitost. Důležité tedy je, aby se $\mathrm{v}$ průběhu života dalo žákům dostatek podnětů $\mathrm{k}$ tomu, aby se některé nadání projevilo a aby se stalo manifestované.

Podle Laznibatové (2012) je žák s nadáním, neboli zázračné dítě, ten, kdo vyniká v jedné nebo více oblastí. Jeho vývoj přirovnává zrychlenému filmu, nebot u něj dochází $k$ vývoji jako u všech ostatních, ale mnohem rychleji.

\section{VYUČOVÁNÍ A METAKOGNITIVNÍ STRATEGIE}

V současných snahách o rozvoj osobnosti žáka a jeho autonomie se klade stále větši důraz na rozvoj metakognitivních procesů, řešitelských strategií, autokorekci, odhadování a využívání vlastních schopností. $\checkmark$ praxi je rozvoj metakognitivních schopností realizován tím, že žák je veden k pojmenovávání a popisu toho co, jak a proč dělá a používá. Dochází tedy k sebepozorování a uvědomování si vlastního způsobu myšlení a řešení daného problému. Rozvijí se při tom jedinečnost žáka, schopnost verbalizovat své myšlenky a schopnost argumentace. Porozuměním vlastnímu myšlení se u žáka rozvijí i schopnost empatie, která je důležitá pro efektivní tř́dní diskuze.

U žáků s nadáním se může objevit verbalizace vlastních myšlenek jako problém, protože způsob řešení je často vhledový, podvědomý a sami nedokážou popsat, jak na to přišli. Havigerová (2011) tento postup přirovnává chůzi. Když se nás někdo zeptá, jak je možné, že chodíme, začneme se na chůzi soustředit a poté se stane, že 
zakopneme (Havigerová, 2011). Je proto velmi důležité učit se verbalizovat vlastní myšlenky a rozvíjet schopnost argumentace. Učitel to může občas ukazovat i sám na sobě.

\section{CHARAKTERISTIKA PŘEDVÝZKUMU}

V roce 2019 jsme zahájili v rámci doktorského studia výzkum metakognitivních schopností nadaných žáků. V červnu 2019 byl realizován předvýzkum, jehož první výsledky zde prezentujeme. Zúčastnilo se ho pět žáků navštěvující pátý ročník městské základní školy. Všichni žáci, kteří se předvýzkumu zúčastnili, mají diagnostikované intelektové nadání z pedagogicko psychologické poradny.

První částí předvýzkumu byl matematický test, který žáci vyplňovali individuálně. Test byl tvořen nestandardními úlohami, které byly zvoleny z důvodu možnosti získat větší množství rozdílných řešení. Tři úlohy z pěti byly vybrány z učebnice matematiky pro 5. ročník, nakladatelství Fraus (2011), čtvrtá úloha z matematické soutěže Klokánek (ročník 2015) a pátá úloha z publikace Rozvíjíme matematické nadání žáků náměty pro 1. stupeň základní školy (Zelendová, Lišková, Nováková, 2017). Z učebnice matematiky byly vybrány dva typy úloh: i. úloha typu zebra, která byla upravená, aby zadání bylo složitější; ii. aritmetické úlohy týkající se operace dělení. Úloha zjištující prostorovou představivost byla vybrána ze zadání matematické soutěže Klokánek. Poslední úloha se týká kombinatoriky, vychází z tzv. Teorie čtyř barev.

Úlohy do testu byly řazeny takto: První úlohou je úloha typu zebra, z důvodu největši časové náročnosti a odolnosti vưči standardním postupům. Poté následují aritmetické úlohy a úloha na prostorovou představivost. Poslední úlohou je úloha vycházející z Teorie čtyř barev.

Tab. 1 Shrnutí řešení žáků

\begin{tabular}{|c|c|c|c|}
\hline \multirow{2}{*}{ Úloha } & \multicolumn{3}{|c|}{ Žák } \\
\hline & A & B & C \\
\hline úloha typu zebra & - zápis do tabulky & - zápis do tabulky & - zápis do řádků \\
\hline aritmetická úloha & $\begin{array}{l}\text { - použil metodu } \\
\text { zobecnění } \\
\text { - postupoval po } \\
\text { násobcích pěti }\end{array}$ & $\begin{array}{l}\text { - použil metodu } \\
\text { zobecnění }\end{array}$ & $\begin{array}{l}\text { - použil metodu } \\
\text { zobecnění }\end{array}$ \\
\hline $\begin{array}{l}\text { úloha vycházející } \\
\text { z teorie čtyř barev }\end{array}$ & $\begin{array}{l}\text { - použil symboly } \\
\text { k doplňování barev } \\
\text { - použil různě barevné } \\
\text { pastelky } \\
\text { - postupoval postupně, } \\
\text { od prvního obrázku } \\
\text { k poslednímu }\end{array}$ & $\begin{array}{l}\text { - vybarvoval útvary } \\
\text { - použil pastelky jedné } \\
\text { barvy (různé odstíny) } \\
\text { - postupoval postupně, } \\
\text { od prvního obrázku } \\
\text { k poslednímu } \\
\text { - pod obrazce označil, } \\
\text { který je správně vyřešen } \\
\text { a který ne }\end{array}$ & $\begin{array}{l}\text { - vybarvoval útvary } \\
\text { - použil pastelky, jejichž } \\
\text { barvy si nebyly podobné } \\
\text { - postupoval postupně, } \\
\text { od posledního obrázku } \\
\text { k prvnímu }\end{array}$ \\
\hline
\end{tabular}

O průběhu řešení testu byl pořízen videozáznam. Žáci mohli úlohy přeskakovat, když něčemu nerozuměli, mohli se doptávat. $\mathrm{K}$ vyřešení úloh mohli též použít manipulativní pomůcky.

Po vyřešení úloh následoval polostrukturovaný rozhovor, ve kterém byly pokládány otázky na obtížnost úloh, sebehodnocení, dovysvětlení řešení. Kvưli možnosti porovnat vhodnost získávání dat byly vedeny rozhovory různě - po vyřešení celého matematického testu, nebo po vyřešení konkrétní úlohy.

V předvýzkumu jsme vyhodnocovali všechny tři složky - řešení samotného matematického testu, rozhovor a videozáznam. Předvýzkum probíhal individuálně, nebyl časově omezen. Průměrná doba řešení byla 30 minut. 


\section{KVALITATIVNÍ ANALÝZA POSTUPU ŘEŠENÍ U VYBRANÝCH ÚLOH}

Ke kvalitativní analýze řešení byly vybrány jen tři úlohy z testu a jsou analyzovány u třech žáků (tab. 1). Tyto úlohy byly vybrány, nebot' měly nejvíce rozdílná žákovská řešení. Jsou to následující úlohy: i. úloha typu zebra, ii. aritmetická úloha - úloha zaměřená na dělení, iii. úloha vycházející z Teorie čtyř barev.

Analýza řešení byla zaměřena na to, zda žák úlohu vyřešil správně, či nikoliv, jak pracoval s textem - tzn., zda se k němu vracel, zda a jak si v něm označoval použité informace, jakým způsobem pracoval a způsob práce - tzn., jakým způsobem si zaznamenával řešení.

Všichni žáci řešili úlohy postupně. Kromě žáka $C$, který úlohu typu zebra řešil průběžně, v průběhu řešení ostatních úloh.

\section{Tab. 2 Řešení úlohy}

\begin{tabular}{|l|c|c|c|c|c|}
\hline Značka auta & Citroen & Škoda & Hyundai & Peugeot & Mazda \\
\hline Cena & 261000 Kč & 294900 Kč & 259900 Kč & 307000 Kč & 520900 Kč \\
\hline Barva & zelená & žlutá & bílá & modrá & červená \\
\hline pořadí & 1. & 2. & 3. & 4. & 5. \\
\hline
\end{tabular}

\section{ÚLOHA TYPU ZEBRA}

Tato úloha byla vybrána z učebnice Matematiky 5. ročník, nakladatelství Fraus (2011). Následně byla úloha upravena, protože cílem nebylo pouze odpovědět na otázky. Dalším důvodem bylo príběhovou hladinu úlohy více přibližit realitě.

\section{Znění úlohy}

V obchodě je pět aut značek Škoda, Peugeot, Mazda Citroen a Hyundai. Mají různé barvy: zelenou, modrou, žlutou, červenou a bílou. Ceny aut jsou: 261000 Kč, 259900 Kč, 294900 Kč, 307000 Kč a 520900 Kč.

Víme, že Citroen je zelený, Hyundai je o 35000 Kč levnější než Škoda a auto, které stojí 307000 Kč, je modré. Nejdražší auto je Mazda. Nejlevnější auto je bílé. Druhé nejlevnější auto je zelené. Červené auto stojí hned před modrým. Žluté auto stojí hned před bílým. Poslední v řadě stojí nejdražší auto.

\section{Řešení úlohy}

Tato úloha má dvě řešení (tab. 2, 3), což žákům předem nebylo řečeno. Žádný z řešitelů na dvě řešení nepřišel.

\section{Žák A}

\begin{tabular}{|c|c|c|c|c|}
\hline 159900 & 261000 & $30 z 000$ & 294900 & 520900 \\
\hline Bilé & Zelení & Modré & $80 i l u a$ & cervená \\
\hline & 1 & 4. & 2 & 5. \\
\hline
\end{tabular}

$$
\text { CerrenáModrá Bilá Ziutá Zelená }
$$

Obr. 1 Řešení žáka A 


\section{Tab. 3 Řešení úlohy}

\begin{tabular}{|l|c|c|c|c|c|}
\hline Značka auta & Škoda & Hyundai & Peugeot & Citroen & Mazda \\
\hline Cena & 294900 Kč & 259900 Kč & 307000 Kč & 261000 Kč & 520900 Kč \\
\hline Barva & žlutá & bílá & modrá & zelená & červená \\
\hline pořadí & 1. & 2. & 3. & 4. & 5. \\
\hline
\end{tabular}

Žák A si řešení zaznamenával do tabulky. Nejdřive si do ní poznamenal, co je známé, a poté dopisoval ostatní informace. Do tabulky zaznamenal cenu automobilu, název značky a pořadí. Na závěr dopsal barvy automobilů, které si původně vypsal mimo tabulku s řešením. S textem žák $A$ pracoval průběžně, neustále se $k$ němu vracel, potichu jej četl a v zadání úlohy si škrtal informace, které již použil do řešení.

Žák A vyřešil úlohu typu zebra správně. Nalezl pouze jedno řešení úlohy.

Žák B

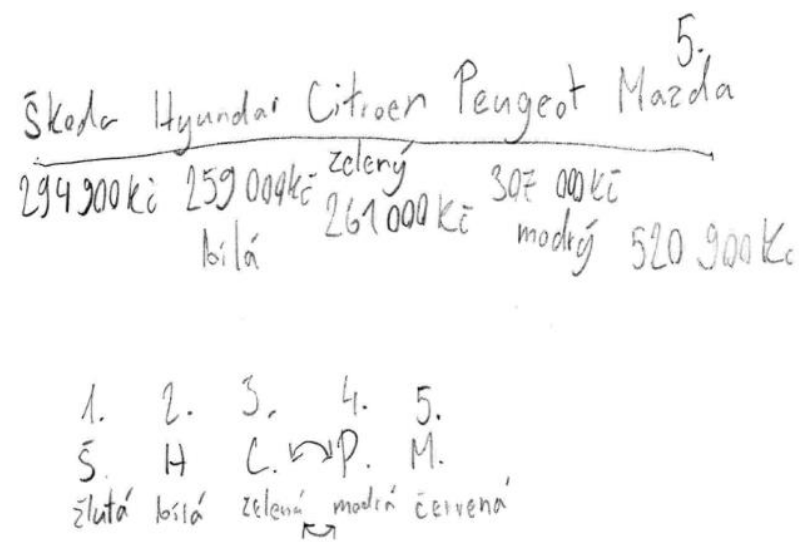

Obr. 2 Řešení žáka B

Žák B si nebyl jistý se zadáním úlohy s řešením po prvním přečtení úlohy. Po druhém přečtením začal úlohy řešit, řešení zaznamenával do tabulky. Vypsal si známé informace do tabulky. Pořadí automobilů následně napsal do další tabulky. Úlohu vyřešil správně. Nalezl pouze jedno řešení úlohy.

\section{Žák C}

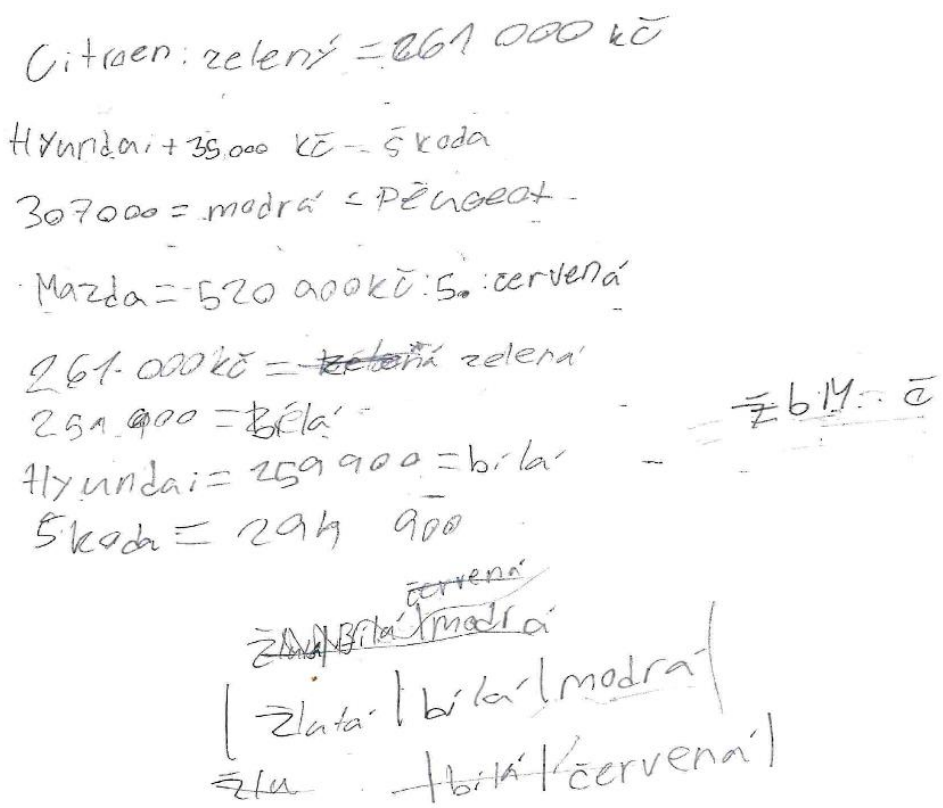

Obr. 3 Řešení žáka C 
Žák C tuto úlohu nepsal zadání do tabulky, ale do řádků, kde jednotlivé informace byly zapsány různě, tzn., že ceny aut, názvy značek a barvy automobilů, které zapsal, byly zapsány podle známých informací. Jednotlivé informace zapisoval od známých po méně známé a podle toho, jak z textu „vyplývaly“. Žákova orientace v textu byla prováděna pomocí ukazování tužkou, díky němuž si ukazoval známé a neznámé informace. Úlohu žák nedořešil. Žák se $k$ jejímu řešení vracel několikrát a nakonec řekl, že ji nechce dořešit.

\section{ARITMETICKÁ ÚLOHA}

Úloha pochází z učebnice Matematiky, nakladatelství Fraus (2011). Nebyla nijak upravována.

\section{Znění úlohy}

Existuje celkem pět dvojciferných čísel, kterými můžeš vydělit číslo 1000 beze zbytku. Najdeš je?

\section{Řešení úlohy}

Dělitele čísla 1000 jsou 10, 20, 25, 40, 50.

Žák A

$$
\begin{aligned}
& 70, x x_{1} 20,15,30,35,40,45,950,55,60,65,70,75,80,85,20,95 \\
& 50-20 \quad 10 \quad 25 \quad 40
\end{aligned}
$$

Obr. 4 Řešení žáka A

Po prečtení zadání úlohy žák inned vypsal tři dělitele čísla 1000 beze zbytku, tzn. dělitele 50, 20 a 10. Nad zbývajícími dvěma žák přemýšlel. Na papír s řešením si vypsal násobky čísla pět. Z násobků vyškrtal čísla, která již jako dělitele vypsal. Poté vyškrtal čísla, která dělitelem být nemůžou - žák řekl, že mu došlo, že dělitelem nemůže být číslo 30, tedy ani jeho násobky. Dalši dvojciferné dělitele hledal jako násobky prvních tř́i vypsaných dělitelů.

\section{Žák B}

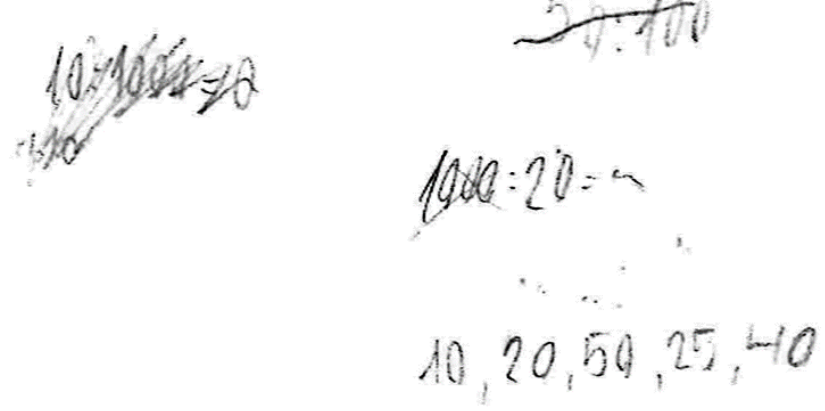

\section{Obr. 5 Řešení žáka B}

Žák B se zeptal na vysvětlení pojmu podíl. Význam pojmu mu byl vysvětlen a zároveň i ukázán. Žák B tvrdil, že významu a užití rozumí. Žák na dvojciferné dělitele přišel bez problému. Výpočet prováděl z čísla 1000 . První tři dělitele, které vypsal, byla čísla 10, 20, 50 - tzn. dělitele, které jsou snadno určitelné zpaměti. Nad zbývajícími děliteli více přemýšlel, ale již nepotřeboval radu a úlohu sám a správně vyřešil. 


\section{Žák C}

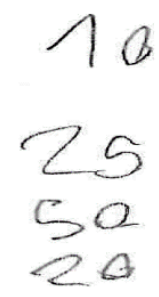

Obr. 6 Řešení žáka C

Aritmetickou úlohu žák $C$ nedořešil. Poslední dvojciferné číslo nenalezl a dořešit ji nechtěl. Po přečtení zadání žák chtěl vysvětlit, co je dvojciferné číslo. Z hlavy žák určil čtyři dělitele $-10,25,50,20$. Nalezené dělitele vypočítal hned. Žák vysvětloval, že čtyři dělitele počítal z čísla 1000 , nedocházelo tedy u něj ke zjednodušení úlohy (tzn., že by dělil číslo 100).

\section{ÚLOHA VYCHÁZEJÍCÍ Z TEORIE ČTYŘ BAREV}

Úloha byla použita z publikace Rozvíjíme matematické nadání žáků - náměty pro 1. stupeň základní školy (Krejčová, 2009 cit. dle Zelendová, Lišková, Nováková, 2017). Úloha nebyla upravována.

\section{Znění úlohy}

Vybarvi obrázky s použitím čtyř barev tak, aby se nikde nedotýkaly stejné barvy.
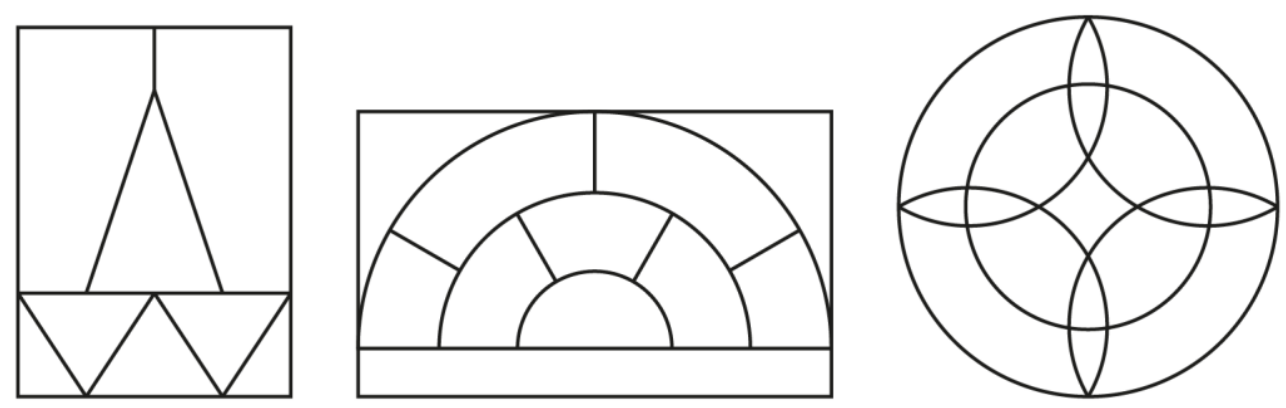

Obr. $7^{2}$ Zadání úlohy

\section{Řešení úlohy}
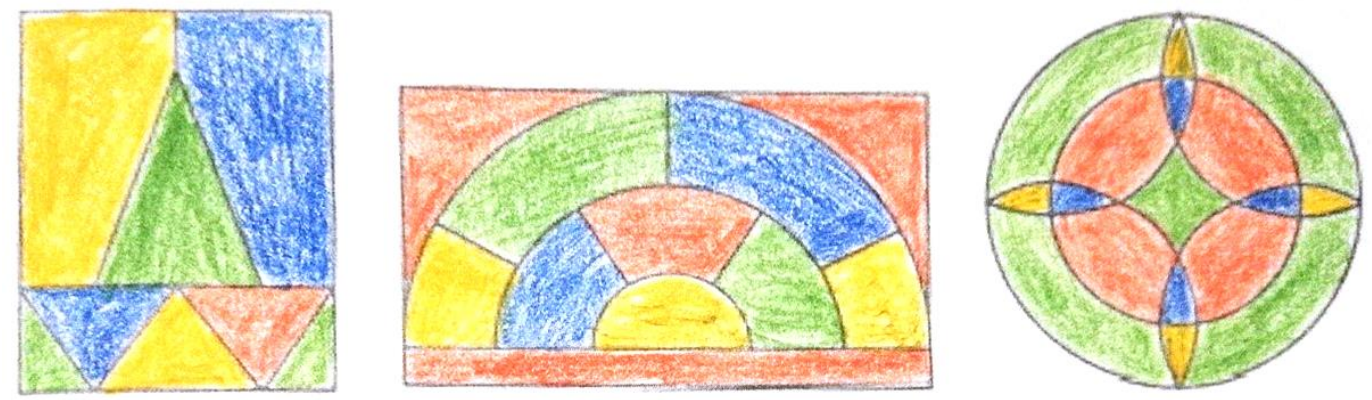

Obr. 8 Řešení úlohy

\footnotetext{
${ }^{2}$ Rozvijíme matematické nadání žáků - náměty pro 1. stupeň základní školy (2017), s. 61
} 
Žák A
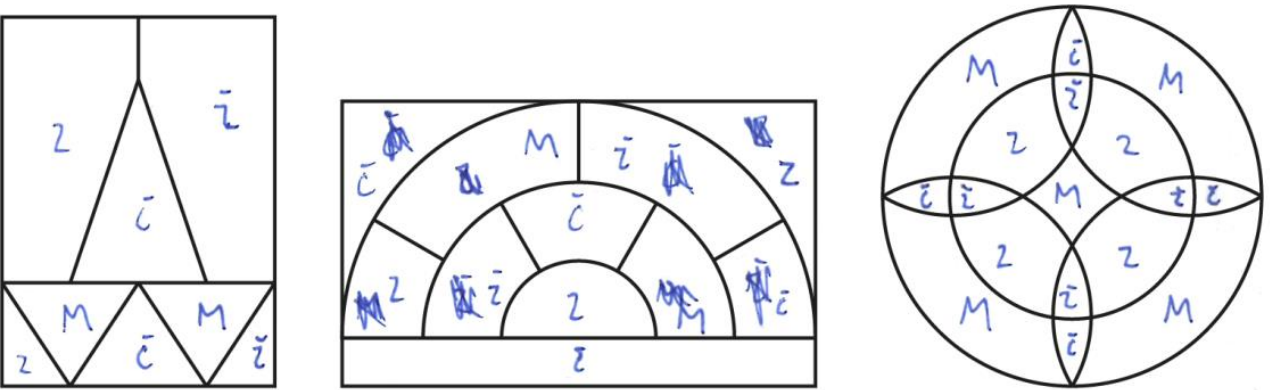

Obr. 9 Řešení žáka A

Žák A použil k vybarvování místo barev pouze symboly k označení barev ( $M, Z, Z$ Ž, Č). Žák postupoval v řešení postupně, od prvního obrazce k posledním. Žák A se nezeptal, zda platí jako dotyk, když se jednotlivé tvary útvaru dotýkají vrcholy. Sám si určil, že ano. Žák nejdřive doplňoval označení jedné barvy a poté postupně dalších. Dokázal si daný obrazec a rozložení barev $v$ něm představit $v$ hlavě. Žák úlohu řešil konceptuálně a vyhodnotil ji jako lehkou. $V$ úloze vyřešil pouze poslední obrazec správně. U prvního obrazce se dotýkají dvě $Z$ a dvě Ž v rohu, u druhého obrazce se dotýkají dvě Č dole.

\section{Žák B}

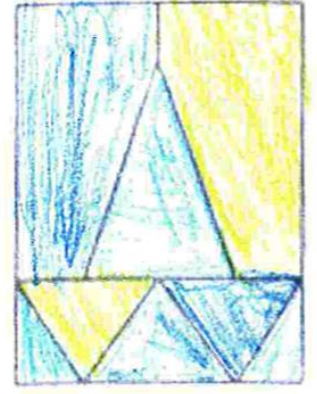

$\sqrt{ }$
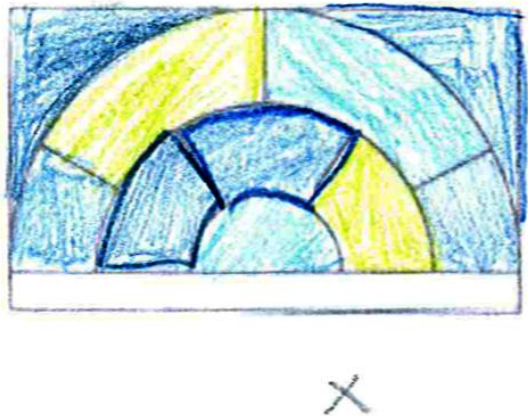

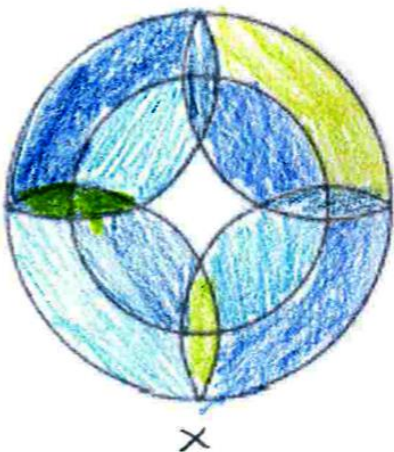

Obr. 10 Řešení žáka B

Žák B úlohu nevyřešil správně. Řešení úlohy vybarvoval. Použil pastelky, které si byly velmi podobné, odstíny modré a zelené barvy. Žák řešil úlohu od prvního obrazce $k$ poslednímu. $V$ průběhu rešení části obrázků vybarvoval postupně, tzn., používal jednotlivé odstíny modré a zelené barvy. První obrázek byl vyřešen správně, ale další dva nikoliv. Sám si je opravit nechtěl a po zeptání, zda si nechce zkontrolovat rešení úloh, odpověděl, že ne. Důvodem bylo, že se mu pletly barvy, nebot' si zvolil podobné odstíny. Žák úlohu ohodnotil jako jednu z těžších.

Žák C
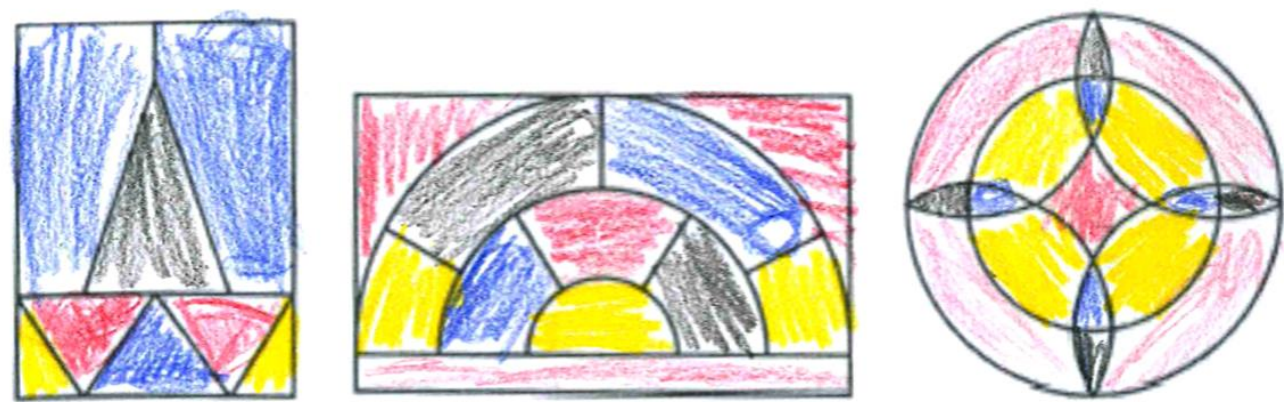

Obr. 11 Řešení žáka C 
Žák C vybarvoval postupně jednotlivé obrazce. K vybarvování zvolil barvy, které si nejsou podobné. Výběr odůvodnil tím, aby si výsledek dokázal lépe představit. Úlohu začal řešit od posledního obrazce $k$ prvnímu. Na zadání úlohy se žák $C$ jen podíval a hned věděl, jaké bude řešení. Obrazce vybarvoval postupně, tzn. podle toho, jak se jednotlivé barvy sebe navzájem dotýkaly, $v$ průběhu řešení barvy pastelek střídal. $V$ průběhu řešení se žák zeptal, zda se části obrazce dotýkají rohy. Sám si poté vyvodil, že se sebe dotýkají a úlohu vyřešil samostatně. Žák vyřešil správně obrazec prostřední a poslední. U prvního obrazce se žákovi dotýkají dvě modré barvy.

\section{METAKOGNITIVNÍ PROJEVY ŽÁKU゚}

\section{Žák A}

Dle žákova názoru se mu úlohy zdály jednodušší. Řešení aritmetické úlohy bylo u žáka pozoruhodné, nebot' daný způsob řešení, vypisování všech možností a orientace na násobky pěti, použil jako jediný. Žák se nebál užít řešení, které bylo potřeba odůvodnit. $V$ úloze typu zebra žák použil výčet všech známých prvků, které poté doplňoval dalšími informacemi pomocí vylučovací metody. V úloze týkající se teorie čtyř barev pokračoval $\checkmark$ řešení postupně a místo barev použil zástupný prvek, označení barev písmeny.

Žák $A$ uvedl, že má rád nestandardní úlohy, protože si je může řešit po svém. Argumentace výsledku je ovlivněna sebevědomím žáka, protože žák si je stoprocentně jistý, že úlohu vyřešil správně.

\section{Žák B}

Žák B úlohy řešil lehce. Snažil se úlohy vyřešit. V úloze typu zebra si žák nejdříve si vypsal známé informace do tabulky. Poté priirazoval další informace pomocí vylučovací metody. Pracoval samostatně, matematickou terminologii si potřeboval ujasnit, některými pojmy si nebyl jistý. Žák B nevyřešil všechny úlohy správně. Slabou stránkou žáka je jeho nedostatečná cílevědomost $k$ vyřešení úloh a chybí mu také dostatečně rozvinutá schopnost trpělivost. Jakmile neviděl řešení úlohy, nebo v úloze udělal chybu, nechtěl nad ní dále přemýšlet, nebo si opravovat chybu.

\section{Žák C}

Žák C vyřešil nejméně úloh. Sám úlohy nechtěl dořešit. Po zeptání, zda nechce úlohy dořešit, či si je zkontrolovat, nejevil zájem. Svoje řešení úloh si nedokázal obhájit a vysvětlit postup svého řešení. Základní pojmy matematické terminologie neznal. Žák $\mathrm{C}$ se jevil jako málo cílevědomý a málo si věril. Jeho metakognitivní uvažování nebylo tak vyspělé jako uvažování žáka A.

\section{SROVNÁNÍ ŽÁKU゚}

Podle matematického testu, vyhodnocení testu a sebehodnocení žáků měl na nejvyšší úrovni užívání metakognitivních strategií žák A. Jeho řešení bylo správné, jeho sebehodnocení odpovídalo realitě, úlohy řešil nestandardním způsobem, měl dostatek trpělivosti v průběhu řešení a správnost řešení uměl ověrit.

Žák B nevyřešil všechny úlohy správně, řešil je standardním postupem, který se učí během hodin matematiky ve škole. Dbal na ověrení správnosti svých výsledků, který zdůrazňoval, a bylo to pro něj velmi důležité. Po optání, zda chce úlohy dořešit, začal nad nimi znovu přemýšlet. Bylo tedy pro něj dủležité, aby ho někdo jiný pobídl k opětovnému řešení a začal sám pracovat. Pokud ale po chvíli neviděl řešení, úlohu znovu přestal řešit.

Žák C měl podle srovnání s výsledky testu a jeho sebehodnocením, nejnižší úroveň metakognitivních strategií, nebot' úlohy vyřešil nesprávně, nedokázal si svoje řešení obhájit a u většiny úloh nerozuměl zadání a nerozuměl některým matematickým pojmům, které potřeboval vysvětlit. Žák měl nízké sebevědomí a neuměl si obhájit vlastní názor.

\section{ZÁVĚR}

Analýzu řešení žáků pátých ročníků základní školy vnímáme jako jednu z možností, jak zjištovat metakognitivní dovednosti žáků. Tato analýza je základem pro další systematickou práci s těmito žáky v oblasti sociální, kognitivní a metakognitivní. Zároveň slouží jako východisko pro práci učitele s těmito žáky a pro práci s celým kolektivem, nebot ve třídě je zastoupeno širší spektrum žáků a všichni se mohou navzájem od sebe učit. Jestliže se učitel seznámí se stylem, způsobem práce a myšlením žáka, může připravovat úkoly, které budou pro 
všechny žáky výzvou. Protože když žák uvidí řešení hned, úloha pro něj není zajímavá a nepřináší mu žádnou radost z poznání. Na tento typ úloh si může rychle zvyknout a ba naopak bude časem odmítat úlohy, u kterých není řešení vidět na první pohled. Učitel nesmí při výběru vhodných úloh zapomínat na to, že je důležité rozvíjet všechny stránky jedince, tzn. volit vhodné úlohy, které budou rozvíjet všechny oblasti matematiky. Vhodnými úlohami jsou také úlohy, které mají více řešení, protože žáci přemýšlí nad úlohou i po nalezení prvního řešení. Z hlediska autoregulace učení je velmi důležité umět svoje řešení obhájit, umět argumentovat ve skupině, proč a jaký způsob řešení byl zvolen. Proto i v matematice je vhodné volit různé metody a formy práce.

Pro učitele a jeho práci se žáky s nadáním je poznání jejich stylu myšlení a způsobu práce velmi důležité a často i obohacující. Jelikož je intelektové nadání velmi široký pojem, který zahrnuje sedm podtypů, je práce s každým jedincem specifická. Tito žáci mají rádi komplexní úlohy, u kterých mohou projevit svoji tvořivost a nemusí používat běžně známé postupy řešení. Jako učitelé je nepřemlouvejme, aby pracovali pouze tak, jak chceme my, ale nechme jim prostor pro samostatnou a tvořivou práci. Sami dokáží vymyslet spoustu možností řešení. Nechávejme jim čas a prostor pro přemýšlení, argumentaci.

\section{Zdroje}

[1] Calábek, P., Hátle, J., Molnár, J., Zatloukalová, S. (2015). Klokánek. In P. Calábek, J. Hátle, J. Molnár, S. Zatloukalová. Matematický klokan. (pp. 18-25). Olomouc: Univerzita Palackého v Olomouci.

[2] Hartl, P., Hartlová, H. (2000). Psychologický slovník. Praha: Portál.

[3] Havigerová, J. M. (2011). Pět pohledů na nadání. Praha: Grada.

[4] Hejný, M., Bomerová, E., Jirotková, D., Michnová, J. (2011). Matematika pro 5. ročník základní školy. Plzeň: Fraus.

[5] Hošpesová, A., Vondrová N., Tichá M. (2007). Cesty zdokonalování kultury vyučování matematice. České Budějovice: Jihočeská univerzita v Českých Budějovicích.

[6] Janík, T., Knecht, P., Kubiatko, M., Pavlas, T., Slavík, J., Solnička, D., Vlček, P. (2011). Kvalita školy a kurikula od expertního šetření ke standardu kvality. Národní ústav pro vzdělávání, školské poradenské zařízení a zařízení pro další vzdělávání pedagogických pracovníků (NúV), divize VúP.

[7] Laznibatová, J. (2012). Nadané dietáa jeho vývin, vzdelávanie a podporovanie. Bratislava:IRIS.

[8] Průcha, J., Walterová E. \& Mareš J. (2013). Pedagogický slovník, 7. aktualizované a rozšiřrené vydání. Praha: Portál.

[9] Rámcový vzdělávací program pro základní vzdělávání. (2016). Retrieved from: http://www.nuv.cz/ uploads/RVP_ZV_2016.pdf

[10] Říčan, J. (2016). Metakognice a metakognitivní strategie jako teoretický a výzkumný konstrukt a jejich využití v moderní pedagogické praxi. Most: Hněvín.

[11] Štěpáník, S. (2014). Konstruktivismus ve vyučování českého jazyka na střední škole. Nepublikovaná dizertační práce. Praha: Univerzita Karlova.

[12] Štěpáník, S, Chvál, M. (2016). Konstruktivismus jako cesta ke zlepšování výsledků vzdělávání v českém jazyce? Studia paedagogica, 21 (1). 35-56.

[13] Zelendová, E., Lišková, H., Nováková, E. (2017). Rozvijíme matematické nadání žáků - náměty pro 1. stupeň základní školy. Praha: Núv. 